\title{
The Vanishing Essence of Universities of Science and Technology in Kenya: The Role of a University in Changing the World
}

\author{
Amukowa Wycliffe \\ School of Education \\ Mount Kenya University, Kenya \\ Email:kwamukowa@yahoo.com \\ Jeremiah 0. Atancha \\ Economic Policy and Education Research Centre \\ (ECO-PERC) New Jersey, USA \\ Email: joatancha@yahoo.com
}

Doi:10.5901/ajis.2013.v2n2p333

\begin{abstract}
The view that we live in a changing world is undisputable. This way, two aspects emerge, that of elements that change the world, and that of elements that change in the world. Universities like other entities in the world are elements within these spheres of change. Therefore, universities are part of the changing world, while also are elements that could change the world. This paper roots for an understanding that universities of science and technology have a role to play in changing the world in Kenya.
\end{abstract}

Keywords: Science \& Technology, Education, Change, Development, University

\section{Introduction}

In a bid to link higher education funding to society's long-term economic goals, the Kenya Government made proposals to review courses offered by the country's public universities, putting emphasis on science and technology - a shift that could see dozens of popular courses scrapped. The Higher Education Ministry reported that only science and technology students at public universities would in future be assured of government funding. The Higher Education ministry reckons that priority for funding should be based on the actual cost of mounting the course and how it contributes to the achievement of Vision 2030, Kenya's long-term economic blueprint. Technocrats say the move is meant to ensure that universities churn out adequate and relevant skills for the labour market, which is crucial for Kenya's attainment of middle-income economy status in the next two decades - a future anchored on science and technology. Going forward, courses will be funded differently depending on how they contribute to creating the human resources required for economic growth (Nganga 2010).

Nganga (2010) noted that some educationists faulted the proposal announced, by the Higher Education Ministry saying all courses being offered currently are relevant and the latest move is intended to deny universities funding. The opponents of the move held that all these courses are equally important as they produce the country's human resources, including those working in museums, historical research and even management. Focusing on science and technology only would be counterproductive, as the economy is driven by multiple variables.

The proposal on review of courses comes at a time when Kenyan universities are reeling from a quality crisis - they are weighed down by overflowing classes, strained facilities and a shortage of lecturers - watering down the quality of learning. For example, Kenya has an estimated 8,000 lecturers and educationists have calculated that nearly double that number is needed to meet the country's higher education needs. The country is also facing soaring demand for higher education as more students seek to increase their opportunities in the labour market, a situation set to intensify as subsidised primary and secondary education programmes contribute to increased school-leaver numbers.

The central issue that linger the proposed review of courses and the funding steps given by the Kenya's Ministry of Higher Education is the essence of a university and its role in the society today. Intertwined in this issue is what 
knowledge is worth having in effort to achieve economic development. It appears that the Kenya Government has chosen to focus on the role of the university in a changing world. This paper calls for an examination into how a university can change a world, rather than the role it should play in a changing world.

\section{Background}

Higher education in Kenya started in 1947 with the British government's plan to build a technical and commercial institute in Nairobi. But it was not until 1951 when a Royal Charter was granted for the establishment of the Royal Technical College of East Africa. However the Asian community in Kenya, Tanzania and Uganda had proposed to build a college in memory of Mahatma Gandhi. To avoid the duplication, the Gandhi Memorial Academy Society agreed to merge its interest with those of the colonial government to setup the Royal Technical College of East Africa. The first student joined in 1956 (SoftKenya.com, n.d).

From SoftKenya.com (n.), it is posted that in 1961, the Royal Technical College became the second university college in East Africa-Royal College Nairobi, a constituent of the university of East Africa which had been inaugurated in 1963. Other constituent colleges were Makerere University College in Uganda and University College, Dar es Salaam, Tanzania. The University of East Africa was dissolved in 1970 and the three East African States set up national universities. This led to the birth of the University of Nairobi. The university's enrolment increased to 9,000 in 1984. By then, it had two constituent colleges, Kenyatta and Egerton, which were later elevated to full university status in 1985 and 1987 respectively.

Moi University, Kenya's second university opened its doors in 1984. Enrolment in the four public universities increased to about 20,000 by 1989/90. But with the double intake of 1990 - when the first graduates of the 8-4-4 system and the last ' $A$ ' level group joined university together - enrolment rose to 41,000. This led to the establishment of Jomo Kenyatta University of Agriculture and Technology in 1994, Maseno University in 2000 and the Western University college of Science and Applied Technology in 2002. Between 1970 and 1984, 10 private universities were established. By 1995, they had increased to 12 with an enrolment of more than 4,000. Public universities were allowed to introduce Module II degree programmes, popularly known as parallel degree programmes, which target public and private sector employees and school leavers.

Focus on universities of science and technology in Kenya is founded on Chapter 250 of the Laws of Kenya. According to Obiero (2013), Chapter 250 of the Laws of Kenya constitutes the Science and Technology Act, established the National Council for Science and Technology (NCST) formed in 1977. This was a move aimed at spearheading the growth of science and technology in education sector in the country for the prosperity of the socio-economic sectors. The Kenyan government, through the Ministry of Higher Education, Science \& Technology released a Sessional Paper No. 14 (2012) that carries policy guidelines to form the fundamental baseline on Reforming Education and Training. This is a focus on ensuring that all the current science and technology based universities practice the mandated procedures and guidelines for quality education in the institutions.

The emphasis of science and technology in universities concerns all the stakeholders of the economy including the financial sector which is the baseline for funding research studies. For instance, an African Development Bank (AfDB) funded programs to improve science, technology and innovation last year (Oyuge, 2013). The funding aimed at enhancing education and training institutions to develop skills that will fit the changing labor market. Masinde Muliro University of Science and Technology (MMUST) is one of the institutions that benefitted, hence boosting its vision of being "a center of excellence in science and technology responsive to development needs of society through engagement in dynamic knowledge creation and application" (MMUST, n.d.).

At the time of writing this paper, Kenya had six universities based on science and technology, whose visions and missions carry the scientific themes. The universities include Jomo Kenyatta University of Agriculture and Technology (JKUAT), Masinde Muliro University of Science and Technology (MMUST), Dedan Kimathi University of Technology (DKUT), Kiriri Women's University of Science and Technology (KWUST), Meru University College of Science and Technology (MUCST), and Jaramogi Oginga Odinga University of Science and Technology (JOOUST). The universities have all their historical backgrounds aligned on need for innovation, and offer various courses in their respective campuses across the country. A general perspective locates the main campuses of the universities in Central province for JKUAT, MUCST, and DKUT, Nairobi province for KWUST, Western province for MMUST, and Nyanza province for JOOUST. 
As universities of science and technology find justification and continue to mushroom in Kenya, there is need to have them change the Kenyan community, rather than serve the changing Kenyan community. This paper argues that the proposal by the Government to fund only science based courses emanates from the changing economic times that have led to low funding. It is the position of this paper that rather than be limited by poor economic situations, universities of science and technology in Kenya could change the economic fortunes of the country by focusing on their essence, thereby having a role in changing the world.

\title{
3. Essence and the Role of a University in changing a World: Drew Gilpin Faust
}

Drew G. Faust (n.d), President of Harvard University (http:// president. harvard.edu/speeches/ faust/071012 installation.php), in a speech tells us what role a university should play in changing a world. Faust (ibid) says that the essence of a university is that it is uniquely accountable to the past and to the future - not simply or even primarily to the present. A university is not about results in the next quarter; it is not even about who a student has become by graduation. It is about learning that molds a lifetime, learning that transmits the heritage of millennia; learning that shapes the future. A university looks both backwards and forwards in ways that must - that even ought to - conflict with a public's immediate concerns or demands. Universities make commitments to the timeless, and these investments have yields we cannot predict and often cannot measure. Faust puts it that:

\begin{abstract}
Universities are stewards of living tradition (...) in (...) libraries (...) in our departments of classics, of history and of literature. We are uncomfortable with efforts to justify these endeavors by defining them as instrumental, as measurably useful to particular contemporary needs. Instead we pursue them in part "for their own sake," because they define what has over centuries made us human, not because they can enhance our global competitiveness. We pursue them because they offer us as individuals and as societies a depth and breadth of vision we cannot find in the inevitably myopic present. We pursue them too because just as we need food and shelter to survive, just as we need jobs and seek education to better our lot, so too we as human beings search for meaning. We strive to understand who we are, where we came from, where we are going and why. (Faust: http://president.harvard.edu/speeches/ faust/071012 installation.php).
\end{abstract}

Faust (ibid) maintained that for many people, the four years of undergraduate life offer the only interlude permitted for unfettered exploration of such fundamental questions. But the search for meaning is a never-ending quest that is always interpreting, always interrupting and redefining the status quo, always looking, never content with what is found. An answer simply yields the next question. This is in fact true of all learning, of the natural and social sciences as well as the humanities, and thus of the very core of what universities are about. By their nature, universities nurture a culture of restlessness and even unruliness. This lies at the heart of their accountability to the future. Education, research, teaching are always about change - transforming individuals as they learn, transforming the world as our inquiries alter our understanding of it, transforming societies as we see our knowledge translated into policies, or translated into therapies, like those our researchers have designed to treat macular degeneration or to combat anthrax. The expansion of knowledge means change. But change is often uncomfortable, for it always encompasses loss as well as gain, disorientation as well as discovery. Faust holds that:

\begin{abstract}
We live in a time when knowledge is ever more vital to our societies and economies, in a world of rapidly circulating capital and people and of revolutionary communication technologies. Knowledge is replacing other resources as the main driver of economic growth, and education has increasingly become the foundation for individual prosperity and social mobility (...) Higher education generates broader economic growth as well as individual success. For example, a recent study determined that universities contributed nearly 60 billion pounds to the economy of the United Kingdom in 2007-08. And, of course, this impact is not just national but global. A ferment of ideas and innovation accompanies proliferating exchanges of faculty and students. UNESCO reports a 57\% increase in the numbers of those studying outside their home countries in just the past decade (Faust:http://president.harvard.edu/speeches/ faust/071012installation.php).
\end{abstract}

Faust (ibid) discusses that often universities' international initiatives are framed as a competitive necessity-for the standing of our institutions, for the global success of our nations and their economies. But if these are competitions, they are ones in which everyone can win-through the partnerships they generate, in the opportunities they open, in the fields and the minds they expand. Indeed, as other institutions falter in dispiriting succession, universities nurture the hopes of 
the world: in solving challenges that cross borders; in unlocking and harnessing new knowledge; in building cultural and political understanding; and in modeling environments that promote dialogue and debate. This description captures an essential part of what universities are and why we need them, why we have looked to them as zones of openness since the first Studia Generalia in Paris and Bologna attracted students from across medieval Europe to study law, theology, philosophy and medicine, disciplines that even then extended beyond nations and across borders.

According to Faust (ibid), the global recession has produced an even more direct threat to the growth and health of higher education-a financial one. While the knowledge economy drives and indeed requires the unprecedented growth of higher education, in many places university budgets decline, and courses, faculty and opportunities are cut back, even as enrollments and expectations rise. Faculty and staff have faced furloughs, layoffs and salary reductions; students have seen significant tuition increases and diminished numbers of available places. Faust mentions that:

\title{
(...) We are caught in the paradox of celebrating the global knowledge economy and simultaneously undermining its very foundations (...) (Faust: http://president.harvard.edu/ speeches/faust/071012installation.php).
}

In his speech, Faust says that the nature of the controversies about costs and budget reductions can alert us to another threat. There is a danger that the focus on higher education as the fundamental engine of economic growth is proving so powerful that it will distort our understanding of all that universities should and must be. Such assumptions can, for example, encourage a devaluation of basic scientific research, of investigation that may not yield immediate payoffs or solve concrete problems. The intensely competitive global economy has driven governments, everywhere critical partners to higher education, to demand more immediate, tangible returns on their investments. Too often such an emphasis on the short term can mean especially painful cuts for disciplines whose value, though harder to measure, is no less real. Faust maintained that:

\begin{abstract}
As stewards of centuries-old traditions of higher learning, we must work to assure that the understandable effort to promote what is valuable not eclipse our support for what is invaluable. When we define higher education's role principally as driving economic development and solving society's most urgent problems, we risk losing sight of broader questions, of the kinds of inquiry that enable the critical stance, that build the humane perspective, that foster the restless skepticism and unfounded curiosity from which our profoundest understandings so often emerge. Too narrow a focus on the present can come at the expense of the past and future, of the long view that has always been higher learning's special concern. How can we create minds capable of innovation if they are unable to imagine a world different from the one in which we live now? (Faust: http:// president.harvard.edu/speeches/ faust/071012installation.php).
\end{abstract}

History, according to Faust (ibid) teaches contingency; it demonstrates that the world has been different and could and will be different again. Anthropology can show that societies are and have been different elsewhere-across space as well as time. Literature can teach us many things, but not the least of these is empathy-how to picture ourselves inside another person's head, life, experience-how to see the world through a different lens, which is what the study of the arts offers us as well.

Faust (ibid) argues that:

Economic growth and scientific and technological advances are necessary but not sufficient purposes for a university. And within the domain of science, universities have a distinctive obligation to nurture and fulfill the deep human desire to understand ourselves and the world we inhabit and inherit, from the smallest elementary particle to the sweep of the galaxies-even when there is no practical application close in view and even as we rightly accelerate our efforts to harvest new technologies from knowledge in its most basic form. It is worth remembering that the most transformatively useful of scientific discoveries often trace their origins to research born of sheer curiosity about who we are and how we can fathom the most intriguing mysteries of the natural world.

The ideal and breadth of liberal education that embraces the humanities and arts as well as the social and natural sciences is at the core of (...) philosophy of undergraduate education and is embodied in the "General Education" requirements that account for a quarter to a third of each student's course work. But this liberal arts ideal confronts challenges (...) in a world so intent on bottom lines and measures of utility. At the heart of the liberal arts and fundamental to the humanities-and indeed central to much of scientific thought-is the capacity for interpretation, for 
making meaning and making sense out of the world around us. We are all bombarded with information. That is a defining aspect of the new global knowledge economy and the digital platforms on which it rests (Faust, ibid). Faust observed that:

(...) students spend almost every waking hour attached to some information-generating device-a cell phone, an iPhone, a BlackBerry, an iPad. They are tweeting or googling or instant messaging or e-mailing. What are they meant to do with all this information? How do they digest and evaluate it? If we are to depend on a knowledge economy, how are we to understand what is actually knowledge-or, we might say, signal-as contrasted with what is mere information-what we would call noise? Education measured only as an instrument of economic growth neglects the importance of developing such capacities. It misses the fact that we are all interpreters; it ignores that some things are not about "facts" but about understanding and meaning.

This kind of understanding, in the mind of Faust (ibid) lies at the essence of a university. Meaning is about interpretation. It is about understanding the world and ourselves not only through invention and discovery, but also through the rigors of re-inventing, re-examining, and reconsidering. Meaning is about remembering what we have forgotten, now in a new context; it is about hearing and seeing what is right in front of us that we could not before hear or see; it is about wisdom that must be stirred and awakened time and again, even in the wise. In this regard, Faust puts it that:

\begin{abstract}
An overly instrumental model of the university misses the genius of its capacity. It devalues the zone of patience and contemplation the university creates in a world all but overwhelmed by stimulation. It diminishes its role as an asker of fundamental questions in a world hurrying to fix its most urgent problems. We need both. There is no one model for a university's success, no disembodied "global research university" to which we all should aspire. From the beginning, universities have drawn power from the creative tension between the search for applied knowledge and the devotion to knowledge pursued for its own sake, for the simple satisfaction of curiosity.
\end{abstract}

\title{
4. Classification and Essence of Universities
}

According to llemobade (n.d), universities can be classified as: Conventional, Technological or Open. Conventional University is a multipurpose one which aims to train all round excellence in sciences and humanities. It is generalist in its approach and in its emphasis. The Technological University on the other hand, has as its focus as the application of knowledge for "the specific purpose of fostering technological advance, its strength is practical. The Open University is essentially an improvement of the extension service which exploits the media and printed word for the specific purpose of bringing higher education into the homes. It is a pragmatic approach to solving increasing demands for higher education at less cost.

The need for a University of Technology stems from the well-founded conviction that science in its applied form has had minimal impact on total national effort in development. If therefore, technology is regarded as the main pillar of drive towards self-sufficiency, it is only right and proper that something concrete be done to give expression to the feeling. Hence Universities of Technology are established. llemobade (n.d) writes that:

(..) Universities of Technology are by their very nature, an innovation in the nation's educational system and in drive to achieve self-reliance in the development of higher education and high level manpower resources (...) These Universities are not just additional universities, not just an expansion of university opportunity: they must; be different from the traditional universities which we inherit from the past (...) (llemobade, n.d:5)

Universities of Technology must aim at not merely imparting theoretical knowledge, but, at giving greater emphasis to practical experience in the field and the development of appropriate skills by their students.

(...) in other words the products of these Universities must be finished products" so to speak, in the sense that they can be gainfully employed, within their fields of specialization, on graduation (...) (Ilemobade, n.d:5).

Ilemobade (n.d) notes that some have argued that the Universities of Technology are at best a duplication of faculties of engineering and technology in conventional universities and should not be established to compete for scarce resources which could have been used to revamp and expand existing faculties of engineering and technology in the conventional universities. In this regard llemobade (n.d) holds that: 
(...) Fortunately, many people (...) hold a different view. First, just as it is much more difficult to mould the character and growth of an adult than those of a child, so it is with the conventional universities vis-à-vis universities of technology (...). Second, universities of technology are established for a specific purpose of generating technology, whereas the conventional universities, even when they tried to generate technology, have significant institutional constraints militating against the sustenance of technological tempo, for example, the fierce competition for resource allocation. Third (...) the establishment of universities of technology hinges on the need $f$ to facilitate indigenous technological changes and thus obviate the craze to depend on technology transfer which is a mirage (...). Fourth, the universities of technology would serve as a potent catalyst for creating technology culture in a country. (Ilemobade, n.d:6).

\subsection{The Mission of Universities of Technology}

According to llemobade (n.d), an institution needs a sense of mission for, survival and sense of mission implies a realization that choices have, to be made about its role. If we are to properly evaluate the role of universities of technology in national development, therefore, we must be able to see distinct roles and orientation as reflected in their objectives. llemobade (n.d) discusses that while universities have different patterns of evolution, their purposes could generally be said to be to:

(...) (a) assist through training with programmes in manpower development (...) (b) advance the frontiers of knowledge through searching (...) for truth, discovering, storing and disseminating knowledge (...) (c) provide service through constant interaction with the community and be critics of society (...)(Ilemobade, n.d:6)

The zeal with which any university pursues these functions would depend on its human and material resources. In the case of the universities of technology the objectives are:

(a) to encourage the advancement of learning and hold out to all persons without distinction of race, creed, sect or political conviction the opportunity of acquiring higher education on technology (...); (b) to develop and offer academic and professional programmes leading to the award of diplomas, first degrees, postgraduate research and higher degrees which emphasize meaningful, adaptive, technical, maintenance, developmental and productive skills in the engineering, scientific, agricultural, medical and allied professional disciplines with the aim of producing socially mature men and women with capability not only to understand, use and adapt existing technology but also to improve on it and develop new ones;

(c) to act as agents and catalysts; through postgraduate training, research and innovation for the effective and economic utilization, exploitation and conservation of the countries natural, economic and human resources; (d) to offer to the general population, as a form of public service, the results of training and research and to foster the practical applications of these results; (e) to establish appropriate relationships with other national institutions involved in training, research and development of technologies (...)(f) to identify the technological problems and needs of the society and to find solutions to them within the context of overall national development; $(g)$ to provide and promote sound basic scientific training as a foundation for the development of technology and applied sciences, taking into account indigenous culture and the need to enhance national unity; (h) to undertake any other activities appropriate for a University of Technology of the highest standard. (llemobade, n.d:6f)

\subsection{The Objectives of the Universities of Science and Technology in National Development}

Ilemobade (n.d) argues that if the Universities of Technology must be relevant to national development, the objectives and orientation must reflect national aspirations in technology, the major ones being:

(a) the supply of indigenous technological manpower through training and retraining;(b) the development of appropriate technologies for the utilization of our agricultural and mineral resources; and (c) the sourcing of industrial raw materials. (llemobade, n.d:8)

\section{An Overview of Universities of Science and Technology in Kenya}

As at the time of writing this paper (February, 2013) Kenya had six universities based on science and technology. These universities are: Jomo Kenyatta University of Agriculture and Technology (JKUAT), Masinde Muliro University of Science and Technology (MMUST), Dedan Kimathi University of Technology (DKUT), Kiriri Women's University of Science and 
Technology (KWUST), Meru University College of Science and Technology (MUCST), and Jaramogi Oginga Odinga University of Science and Technology (JOOUST).

\subsection{Jomo Kenyatta University of Agriculture and Technology (JKUAT)}

Jomo Kenyatta University of Agriculture and Technology (JKUAT) was started by the Government of Kenya with the assistance from the Japanese Government in 1981 as a Middle Level College in the name of Jomo Kenyatta College of Agriculture and Technology (JKCAT). On 4th May 1981, the first group of students joined the college, and later, in April 1984, graduated with Diploma Certificates in Food Technology, Agricultural Engineering and Horticulture. On 17th March 1982, the College was formally opened. On 1st September 1988, through a legal Notice, JKCAT became a constituent College of Kenyatta University under the Kenyatta University Act (CAP 210C). JKCAT changed its name to Jomo Kenyatta University College of Agriculture and Technology (JKUCAT), and finally established as a University with inauguration on 7th December 1994 through the JKUAT Act hence JKUAT.

JKUAT posts on it website (www.jkuat.ac.ke..) that it envisions being a University of global excellence in Training, Research and Innovation for development. The university has its mission as offering accessible quality training, research and innovation in order to produce leaders in the fields of Agriculture, Engineering, Technology, Enterprise Development, Built Environment, Health Sciences, Social Sciences and other Applied Sciences to suit the needs of a dynamic world. JKUAT has a motto that emphasizes on research and innovation in higher education, with objectives steered towards collaboration, effective role and cooperation in technological advancement in higher learning. The university has a total of eight core values that include quality, teamwork, transparency, accountability, professionalism, innovativeness, integrity and dynamism. In addition, JKUAT has a university philosophy that reiterates on endeavors in attracting, developing, motivating and retaining a skilled and consultative workforce.

JKUAT offers a variety of courses in certificate, diploma, bachelor and postgraduate studies. The certificate courses comprise of bridging in Mathematics, certificate in HIVIAIDS Management, and certificate in Information Technology. The postgraduate courses comprises of Masters in fields of business, agriculture, engineering, physical sciences, management, among others. The postgraduate courses also include philosophy of doctorates in engineering, mathematics, physical sciences and business management. JKUAT has a category of bachelors' programs in information technology, management, chemical sciences, biological sciences, engineering, and others. Diploma courses in JKUAT include Diploma in Clinical Medicine, Diploma in HIVIAIDS Management, Diploma in Architecture, Diploma in Business Administration, Diploma in Business Information Technology, Diploma in Food Technology Diploma in Information Technology and Diploma in Purchasing \& Supplies Management.

JKUAT has partnered and collaborated with several institutions both within and outside Kenya to facilitate its research and innovation in its training. For instance, the university collaborated with the African Advanced/level Telecommunication Institute - Nairobi in 2009/2013 in Cisco training, and with the Bourne Mouthe University - UK in 2010/2015 in capacity building. Other institutions of collaboration are Denver University of USA, Kaduna Polytechnic of Nigeria, Kaisers Lautern University of Germany, Oslo School of Architecture of Sweden, among many others.

\subsection{Kiriri Women's University of Science and Technology (KWUST)}

KWUST is privately owned, and trains only women. The university was incepted with an objective to bridge the gap in gender parities in education in the region. The University posts on its website that:

\section{(...) the university has been transforming the lives of many young women, not just in Kenya and Africa but the world in general (http://www.kwust.ac.ke).}

The Government of Kenya, through the Commission of Higher Education, issued a Letter of Interim Authority on $15^{\text {th }}$ May 2002 in the set up of the institution. KWUST has three schools in categories of training that include School of Business and Management, School of Computer and Information Technology, and School of Science (Mathematics, Physics, biological Sciences, Environmental Science, and Chemistry).

The KWUST vision is to be a centre of academic excellence in the scientific and technological formation and promotion of the full and holistic development of the individual as a responsible member of the human community. Its mission is to educate and train individuals in the search for truth and knowledge through scientific methods while the 
philosophy holds that science and technology is the tool to reap and utilize resources sustainably, with a motto of using education to empower women. Among its core values is excellence, patriotism, respect, professionalism, transparency, among others.

KWUST offers causes in bachelors' degrees, diplomas, bridging and pre-university. Degree courses include Bachelor of Science in Computer Science and Mathematics, whole the diplomas are in Business Administration, Portfolio Management, and ICT. Bridging courses are offered for Mathematics, English and Physics. On the other hand, the preuniversity courses are designed to develop skills $n$ learning before joining for higher courses. However, the university has upcoming courses which include:

\section{(...) Bachelor of Science in Information Systems; Diploma in Computer Programming; Diploma in Information Systems, Bachelor of Science in Nursing; Diploma in Nursing (...) Bachelor of Law (LLB); Diploma in Law; Bachelor of Education (Science Option); Bachelor of Education (Humanities and Arts Option); Postgraduate Diploma in Education (...) (http://www.kwust.ac.ke).}

Kiriri Women's University of Science and Technology has partnered with other institutions to develop its academics. For instance, Kiriri is a member to the Women's Education Worldwide which brings together Presidents, Vice Chancellors, Chief Academic Officers of Women's Colleges and Universities from around the world. Through this partnership, KWUST has achieved in collection and dissemination of data about women's institutions.

\subsection{Dedan Kimathi University of Technology (DKUT)}

Dedan Kimathi University of Technology developed from a community project, and then known as Kimathi Institute of Technology (KIT) in 1972. The first students were admitted into the institution in 1978, whereby it grew to one of the leading institutions in Kenya in the training of Certified Public Accountants. The Institute was upgraded to University status in 2007 under the constituent of Jomo Kenyatta University of Agriculture and Technology. On 14th December, 2012, the institute was granted a charter to become a fully-status university, hence the name Dedan Kimathi University of Technology (DKUT). The university's motto is to Better Life through Technology, while the vision statement seeks a technological University that excels in quality Education, Research and Technology for national development. The university's mission is providing learning that recognizes diversity while incorporating research, technology and innovation for relevant human resources in national development. The philosophy of DKUT calls for being as good as the best in the world. DKUT has six core values namely innovation, scholarship, diversity, reliability, teamwork, and nature and heritage (http://dkut.ac.ke).

DKUT offers courses for both graduates and undergraduates. School of engineering offers Masters in Industrial Engineering and Management, and Bachelors in Engineering in electrical and electronic, telecommunication and information, mechanic and civil. School of Business offers undergraduate, graduate (MBA and PhD), and Executive Education programs. Masters in Business Administration have options for Leadership and Organizational Management, Accounting, Finance, International Business, Marketing, and Strategic Management. Bachelors' programs are in Purchasing and Supplies Management (BPSM), Business Information Technology (BBIT), Commerce (BCOM) and Business Administration (BBA). Diploma courses in the School of business are Diploma in Business Administration and Diploma in Purchasing and Supplies Management while Certificate course is offered in County Governance.

Moreover, DKUT has schools of Science categorized into two as Computer Science and Health Science that offer various programs in bachelors and diplomas. The university has various institutes that include institute of geomatics, gis \& remote sensing (IGGRS) that offer respective courses. Institute of Technical and Professional studies offers programs such Diplomas and Certificates in Clothing and Fashion Design, Furniture Technology and Interior Design, Building Technology, and Metal Work, Welding and Design. Other institutes in the university are institute of food bio-resources which offers courses in coffee technology, and institute of Tourism and Hospitality Management.

\subsection{Masinde Muliro University of Science and Technology (MMUST)}

Masinde Muliro University of Science and Technology was founded 5th January, 1972 through community self-help spirit, and was by then called Western College of Arts and Applied Sciences (WECO). The first batch of students at WECO enrolled for certificate and diploma courses in 1977. The courses consisted of the programs in mechanical and motor 
vehicle, electrical, electronic, agriculture, architecture, among others. The institutions' name hanged to Western University College of Science and Technology (WUCST) in December 2002 as a constituent college of Moi University. Later on, in 2007 WUCST was elevated to a fully- status university hence the name changed to Masinde Muliro University of Science and Technology (http://www.mmust.ac.ke.) .

MMUST envisions being a center of excellence in science and technology responsive to development needs of society through engagement in dynamic knowledge creation and application. The university's mission is bound on widening knowledge dissemination through integrating science and technology, research and innovations. It has a general objective of qualitative contribution to economy through sustainability and equitability. The university's philosophy emphasizes science and technology as an important tool in harnessing resources for development. The university offers courses in engineering, education, social sciences, disaster management, preparedness and mitigation. Other courses include health (Medicine) information technology, among others. MMUST also has Institute of Graduate Studies, Research and Extension (IGSRE), Science and Technology Park and Industrial Linkages (STPIL), Forensic Science, Banking Fraud and Money Laundering Investigations; Corruption Research, Monitoring and Evaluation; Corruption Prevention Methods. Others are Audit and Planning Logistics, Conflict Management and Resolution among others.

\subsection{Meru University College of Science and Technology (MUCST)}

Meru University College of Science and Technology (MUCST) was established in mid-1960s after Kenya's independence to serve the needs of development of the youth in anticipated industries. It started as Meru College of Technology (MECOTECH). In 1979, the college opened its first office in Meru Municipal Hall. In 1983, the first students were admitted for a two year course in Agriculture. In May 1985, a Motor Vehicle Mechanics course was introduced and followed by the Building Technology Craft I - III courses in 1987. Accounts and Secretarial Studies (Intermediate and Final) courses were introduced in September 1992 and May 1993, respectively, which then steered the college into offering diploma and certificate courses in engineering, agriculture and extension, Information Technology, secretarial, building and masonry and business administration, among others (http://www.mucst.ac.ke).

MECOTECH was elevated to a University in 2008 and named the Meru University College of Science and Technology (MUCST). It was established as a constituent college of Jomo Kenyatta University of Agriculture and Technology. In May2009, MUCST admitted its first degree programmes' students in Bachelor of Commerce (B-COM), Bachelor of Business Information Technology (BBIT), and Bachelor of Science in Information Technology (B.Sc. IT). MUCST has a vision of being a world class university of excellence in science and technology.. The university's mission is to provide quality university education for globally competitive graduates through training, research, and innovation while core values are relevance, competitiveness, quality, efficiency, transparency, among others.

MUCST offers a range of courses on programmes under various schools. For instance, the school of information technology and engineering offers Bachelors in computer science, computer technology, Information Technology; and Diploma in IT, Engineering, Building Construction, and certificates in respective courses. The School of Agriculture and Food Science has courses offered in Bachelors degrees of Science in food and technology, Horticulture and Agribusiness, while Diploma courses in Agricultural Education and Extension and in Agriculture. The School of Pure and Applied Sciences which have various Departments including Department of Mathematics and Physics, Department of Chemistry, Department of Biological Sciences and Department of Health Sciences offering respective programmes of Bachelor, Diploma and Certificates. Lastly, MUCST has a School of Business and Economics with three Departments, namely: - Depart of Accounting and Finance, Department of Business management, and Department of Economics, all offering Masters, Bachelors, Diplomas, and Certificate courses(http://www.mucst.ac.ke).

\subsection{Jaramogi Oginga Odinga University of Science and Technology (JOOUST)}

Jaramogi Oginga Odinga University of Science and Technology (JOOUST) was first established as Bondo University College (BUC) through a Legal order No. 56 of 11 th May 2006, and as a constituent college of Maseno University. JOOUST's vision is to become the best in research, training and sustainable development while the mission is to provide quality university education that nurtures creativity and innovation through integrated training, research and community outreach.. The University has six core values namely fairness, professionalism, transparency and accountability, integrity, meritocracy, and gender equity. The philosophy of the university is to use science and technology to create a holistic approach of service to humanity. Courses offered at JOOUST fall within the broad categories of schools as follows: 
School of Education and Social Sciences, School of Biological and Physical Sciences, School of Engineering Sciences and School of Food Security, Agriculture and Biodiversity. The four Schools offer a variety of respective courses from the Doctorate to Diploma ones (http://www.bondo-uni.ac.ke).

\section{The Vanishing Essence of Universities of Science and Technology in Kenya}

It has been shown in this paper that the Government of Kenya proposes not fund non-science oriented courses in the universities as they do not have direct contributions to economic development in the light of Kenya Vision 2030. This proposal seems to have triggered the desire for science and technology based courses hence the seeming growth of science and technology universities in Kenya. This way, this paper argues that the universities of science and technology in Kenya must not lose their essence.

Faust (ibid) discusses that the essence of a university is that it is uniquely accountable to the past and to the future - not simply or even primarily to the present. A university is about learning that molds a lifetime, learning that transmits the heritage of millennia; learning that shapes the future. A university looks both backwards and forwards in ways that must - that even ought to - conflict with a public's immediate concerns or demands. Universities make commitments to the timeless, and these investments have yields we cannot predict and often cannot measure. In this regard, this paper urges that in underscoring their essence, universities of science and technology in Kenya must endeavour both their past and future aspiration.

Ilemobade (n.d) shows that the Universities of Technology are by their very nature, an innovation in the nation's educational system and in drive to achieve self-reliance in the development of higher education and high level manpower resources and not just additional universities, not just an expansion of university opportunity: they must; be different from the traditional universities inherit from the past. From the overview of the current universities of science and technology in Kenya, it is realized that their very essence is getting lost and they are almost just an expansion of university opportunities. One such feature is seen in cases where these universities are offering courses in humanities like law, corruption and education, to mention but a few. Besides offering courses in humanities, these universities are offering courses at certificate and diploma levels, contrary to the fact that universities are meant to offer courses at degree level.

Universities of science and technology in Kenya do not differ from conventional or open universities. According to llemobade (n.d), there are three categories of universities: Conventional, Technological or Open. Conventional University is a multipurpose one which aims to train all round excellence in sciences and humanities. It is generalist in its approach and in its emphasis. The Technological University on the other hand, has as its focus as the application of knowledge for "the specific purpose of fostering technological advance, its strength is practical. The Open University is essentially an improvement of the extension service which exploits the media and printed word for the specific purpose of bringing higher education into the homes. It is a pragmatic approach to solving increasing demands for higher education at less cost.

It is realized from this paper that all the universities of science and technology in Kenya do have schools of humanities, and even some have distance education programmes. This way, it appears, these universities have lost their essence and it is almost meaningless for them to be called universities of science and technology, but they should rather be called university A, or B. Universities of Technology must aim at not merely imparting theoretical knowledge, but, at giving greater emphasis to practical experience in the field and the development of appropriate skills by their students in science and technology fields.

By underscoring their essence, universities of science and technology in Kenya would yield to their parental objectives that include: (a\} to encourage the advancement of learning and hold out to all persons without distinction of race, creed, sect or political conviction the opportunity of acquiring higher education on technology (...); (b) to develop and offer academic and professional programmes leading to the award of diplomas, first degrees, postgraduate research and higher degrees which emphasize meaningful, adaptive, technical, maintenance, developmental and productive skills in the engineering, scientific, agricultural, medical and allied professional disciplines with the aim of producing socially mature men and women with capability not only to understand, use and adapt existing technology but also to improve on it and develop new ones; (c) to act as agents and catalysts; through postgraduate training, research and innovation for the effective and economic utilization, exploitation and conservation of the countries natural, economic and human resources; (d) to offer to the general population, as a form of public service, the results of training and research and to foster the practical applications of these results; (e) to establish appropriate relationships with other national institutions involved in training, research and development of technologies (...)(f) to identify the technological problems and needs of 
the society and to find solutions to them within the context of overall national development; $(\mathrm{g})$ to provide and promote sound basic scientific training as a foundation for the development of technology and applied sciences, taking into account indigenous culture and the need to enhance national unity; (h) to undertake any other activities appropriate for a University of Technology of the highest standard. (llemobade, n.d:6f)

\section{The Role of Science and Technology in Kenya in Changing the World}

This paper argues that there are two ways in which universities of science and technology can serve the world. One is by responding to the changing world, and the second is in changing the world. In this regard, this paper urges the universities of science and technology to be world changing, and by that, roots its foundation in Faust's conceptualization of the university's role in changing a world.

According to Faust ((http:// president.harvard.edu/speeches/ faust/071012installation.php) universities are stewards of living tradition and by their nature, they nurture a culture of restlessness and even unruliness. This lies at the heart of their accountability to the future. The expansion of knowledge means change. But change is often uncomfortable, for it always encompasses loss as well as gain, disorientation as well as discovery. We live in a time when knowledge is ever more vital to our societies and economies, in a world of rapidly circulating capital and people and of revolutionary communication technologies. Knowledge is replacing other resources as the main driver of economic growth, and education has increasingly become the foundation for individual prosperity and social mobility.

In the light of Faust's argument as put in the above paragraph, this paper argues that for the universities of science and technology to be able to change the world, they must invest in knowledge. However, for them to maintain their essence as opposed to conventional universities, they must invest in practical knowledge. For as llemobade (n.d) puts it, universities of technology must aim at not merely imparting theoretical knowledge, but, at giving greater emphasis to practical experience in the field and the development of appropriate skills by their students. Universities of technology are by their very nature, an innovation in the nation's educational system and in drive to achieve self-reliance in the development of higher education and high level manpower resources. These universities are not just additional universities, not just an expansion of university opportunity: they must; be different from the traditional universities which we inherit from the past.

According to Faust (ibid) universities nurture the hopes of the world: in solving challenges that cross borders; in unlocking and harnessing new knowledge; in building cultural and political understanding; and in modeling environments that promote dialogue and debate. This description captures an essential part of what universities are and why we need them, why we have looked to them as zones of openness. This paper urges universities of science and technology to be hopes of the Kenyan people as they pursue their missions. This way, these universities should not be driven by income generation, but rather be at the center of innovation and creation of practical knowledge geared towards changing the world around them.

With regard to the proposal by the Kenya Government to fund only sciences based courses as opposed to humanities, a leaf could be borrowed from Faust's view. Faust says that the nature of the controversies about costs and budget reductions can alert us to a danger that the focus on higher education as the fundamental engine of economic growth is proving so powerful that it will distort our understanding of all that universities should and must be. Such assumptions can, for example, encourage a devaluation of basic scientific research, of investigation that may not yield immediate payoffs or solve concrete problems.

The intensely competitive global economy has driven governments, everywhere critical partners to higher education, to demand more immediate, tangible returns on their investments. Too often such an emphasis on the short term can mean especially painful cuts for disciplines whose value, though harder to measure, is no less real. Faust (ibid) urges that as stewards of centuries-old traditions of higher learning, universities must work to assure that the understandable effort to promote what is valuable not eclipse our support for what is invaluable. When we define higher education's role principally as driving economic development and solving society's most urgent problems, we risk losing sight of broader questions, of the kinds of inquiry that enable the critical stance, that build the humane perspective, that foster the restless skepticism and unbounded curiosity from which our profoundest understandings so often emerge. Too narrow a focus on the present can come at the expense of the past and future, of the long view that has always been higher learning's special concern.

As there continues to be growth of universities of science and technology in Kenya, this paper calls for attention on Faust's observation about science and technology. Faust cautions that economic growth and scientific and technological 
advances are necessary but not sufficient purposes for a university. And within the domain of science, universities have a distinctive obligation to nurture and fulfill the deep human desire to understand ourselves and the world we inhabit and inherit, from the smallest elementary particle to the sweep of the galaxies-even when there is no practical application close in view and even as we rightly accelerate our efforts to harvest new technologies from knowledge in its most basic form. It is worth remembering that the most transformatively useful of scientific discoveries often trace their origins to research born of sheer curiosity about who we are and how we can fathom the most intriguing mysteries of the natural world. Faust puts it that:

\begin{abstract}
An overly instrumental model of the university misses the genius of its capacity. It devalues the zone of patience and contemplation the university creates in a world all but overwhelmed by stimulation. It diminishes its role as an asker of fundamental questions in a world hurrying to fix its most urgent problems. We need both. There is no one model for a university's success, no disembodied "global research university" to which we all should aspire. From the beginning, universities have drawn power from the creative tension between the search for applied knowledge and the devotion to knowledge pursued for its own sake, for the simple satisfaction of curiosity. (Faust: http:// president.harvard.edu/speeches/ faust/071012installation.php).
\end{abstract}

\title{
8. Conclusion
}

In the light of the observations made in this discussion, this paper concludes that universities of science and technology have an essence different from conventional and open universities. By embracing their very essence, universities of science and technology could define and change the world by nurturing and harnessing practical knowledge. Given the value attached to science and technology in Kenya, these universities are at the center of Kenya's desire for change.

\section{References}

Bondo University College website. Accessed February 22, 2013. http://www.bondo-uni.ac.ke./

Dedan Kimathi University of Technology website. Accessed February 22, 2013.http://dkut.ac.ke/

Faust, D.G (n.d). Harvard president on the essence of a university http:// president.harvard.edu /speeches/faust/071012_installation.php Government of Kenya, Ministry of Higher Education, Science \& Technology. (2012). The Fundamental baseline on Reforming Education and Training Sectors in Kenya: The Sessional Paper No. 14 (2012). Retrieved from http:// www.education.go.ke /Documents.aspx?docID=1708

llemobade (n.d). The Role of Universities of Technology in National Development. Federal University of Technology. Akure

Jaramogi Oginga Odinga University of Science and Technology (JOOUST) website. Accessed February 22, 2013. http://www.jooust.ac.ke/

Jomo Kenyatta University of Agriculture and Technology website. Accessed February 23, 2013. www.jkuat.ac.ke

Kiriri Women's University of Science and Technology website. Accessed February 22, 2013. http://www.kwust.ac.ke

Masinde Muliro University of Science and Technology website. Accessed February 22, 2013. http://www.mmust.ac.ke

Meru University College of Science and Technology website. Accessed February 22, 2013. http://www.mucst.ac.ke

Nganga . G. (2010). KENYA: Review of university courses, stress on S\&T Issue No:63. http://www.universityworldnews.com/ article.php?story $=20101002095543231$

Obiero. (January 25, 2013). NCST: Spearheading Science, Technology and Innovation. Retrieved from http://educationnews.co.ke/ncstspearheading-science-technology-and-innovation/.

Oyuge J. (31 January, 2013). Big boon for Science and Technology. Standard Media Group. Retrieved from http://www.standardmedia.co.ke /?articleID=2000076256 \&story title =Big-boon-for-science-and-technology

SoftKenya (n.d) http://softkenya.com/education/higher-education-in-kenya/ Higher Education in Kenya 